\title{
Molecular Confirmation of Contagious Ecthyma Among Goats in Dharmapuri District of Tamil Nadu, India
}

\author{
P.V. Sowmiya ${ }^{1 *}$, K. Ramya $^{1}$, K. Sukmar ${ }^{1}$ and R. Madheswaran ${ }^{2}$ \\ ${ }^{1}$ Department of Veterinary Microbiology, ${ }^{2}$ Department of Veterinary Pathology, Veterinary \\ College and Research Institute, Namakkal - 637 001, Tamil Nadu, India \\ *Corresponding author
}

\begin{abstract}
A B S T R A C T
Keywords

Contagious ecthyma, Goats, Scab, PCR, $B 2 L$ gene

Article Info

Accepted:

02 May 2018

Available Online:

10 June 2018

Contagious ecthyma is one of the most important viral diseases of goats with zoonotic implications and causes economic losses to the farmers. The present study was undertaken to investigate the Contagious ecthyma infections in goats during the month of September and October 2017 in different places of Dharmapuri district. The goats were affected irrespective of their age group and sex. Affected goats had pyrexia, anorexia, nasal discharge and proliferative scab lesions around the mouth suggestive of Contagious ecthyma. The disease was confirmed by polymerase chain reaction targeting B2L gene. It is also screened for Pestedes petits ruminants by polymerase chain reaction targeting $\mathrm{N}$ gene. Affected animals were treated with antibiotic, anti-inflammatory and vitamin B complex injections parenterally. Topically glycerin and boric acid paste or neem oil and turmeric paste was applied to alleviate the lesions. Affected animals were recovered in 2-3 weeks.
\end{abstract}

\section{Introduction}

Contagious ecthyma is a viral disease primarily of sheep and goats caused by Parapoxvirus belonging to family Poxviridae. The disease has been considered benign but it will take serious course if secondary infections with other viruses and bacteria which increase the mortality rate from 10 to 20 percent. The disease has a significant economic impact on rural communities where the marginal farmers are predominantly dependent upon livestock farming as a source of livelihood. The synonyms of disease used in various outbreaks included contagious pustular stomatitis, Contagious ecthyma, ecthyma contagiosum, infectious pustular dermatitis, infectious labial dermatitis, sore mouth, scabby mouth and Orf (De Wet and Murie, 2011). The etiology of Contagious ecthyma disease is type species of the genus Parapoxvirus of subfamily Chordopoxvirinae of family Poxviridae (Nandi et al., 2011; ICTV, 2014). It is an epitheliotropic parapoxvirus that induces proliferative lesions in the skin of sheep, goats, wild ruminants, humans, and very rarely, dogs (Bassioukas et al., 1993; Haig and Mercer, 1998). The virus is ellipsoidal in 
shape (Ishii et al., 1953). The virus in dried scabs were viable from eight months to more than a year at room temperature (Manley, 1934; Newsom and Cross, 1934), but crusts exposed to external conditions lost their infectivity rapidly during summer (Manley, 1934; Aptow, 2010). However, during winter infectivity persisted for at least six months (Boughton and Hardy, 1935).

In sheep and goats, Contagious ecthyma is recognized by the appearance of vesicles, papules and crusty, rapidly growing scabs in the skin of lips and nose of affected animals. In more severe cases, the skin of other areas, such as the eyes, feet, vulva, or udder, may be affected (De la Concha-Bermejillo et al., 1999). The disease usually runs its course in 3-4 weeks. However, prolonged infections and secondary bacterial infections or myasis of affected areas may occur (Abu and Housawi, 1997; Greig et al., 1984; Zamri-Saad et al., 1993). Occasionally, mortality as high as 10per cent have been reported (Gumbrell and McGregor, 1997). The differential diagnosis of Contagious ecthyma from similar vesicular diseases like Pestedes petits ruminants (PPR), blue tongue, foot and mouth disease and other vesicular diseases is perplexed by the similar clinical signs. Hence, the prompt diagnosis of the disease will help to contain the spread of infections within and the nearby herds.

The B2L gene encodes for a highly immunogenic major envelope protein and able to induce both antibody and cell-mediated immune responses. This gene has been used for detection of Contagious ecthyma virus by PCR (Inoshima et al., 2000).

Primers for amplification of $\mathrm{N}$ - gene of PPR virus genome with $351 \mathrm{bp}$ fragment was used for detection of PPR virus. The present study was undertaken to confirm the etiology of the vesicular disease, Contagious ecthyma in sheep and goats.

\section{Materials and Methods}

\section{Collection of samples}

Ten number of scab samples were collected from Contagious ecthyma suspected goat in different places of Dharmapuri district during the month of September and October with the history of pyrexia, anorexia, proliferative scab lesions around the month. The scab samples were collected in a sterile container and stored at $4{ }^{\circ} \mathrm{C}$.

\section{Sample preparation}

The collected scab samples were triturated in a sterile mortar and pestle with sterile normal saline and made into 10 per cent tissue suspension. The mixture was centrifuged at $1800 \mathrm{rpm}$ for $10 \mathrm{~min}$. The supernatant was transferred into a sterile microcentrifuge tube and subjected for DNA extraction.

\section{DNA extraction}

The DNA was extracted from the collected scab materials by Phenol: Chloroform: Isoamyl alcohol method as described by Klein (2004) with slight modifications. The extraction procedure is as follows:

Five hundred microlitre of tissue suspension was taken in a sterile microcentrifuge tube and five hundred microlitre of Phenol: Chloroform: Isoamyl alcohol was added to the tissue suspension. The mixture was centrifuged at 4000rpm for five minutes. The supernatant (aqueous phase) was collected (approximately $300 \mu \mathrm{l}$ ) in a new microcentrifuge tube and equal volume of chloroform was added and gently mixed and centrifuged at 4000rpm for five minutes. The supernatant was collected in another microcentrifuge tube and two volumes of ice cold ethanol were added. The mixture was centrifuged at 12,000 rpm for ten minutes. The 
upper phase ethanol was discarded. Five hundred microlitre of 70 per cent ethanol was added to the precipitate and centrifuged at $14000 \mathrm{rpm}$ for $10 \mathrm{~min}$. The supernatant was removed and the pellet was air dried. The pellet was resuspended in $50 \mu 1$ of Tris EDTA (TE) buffer.

\section{Polymerase Chain Reaction}

The extracted DNA was subjected to PCR for molecular conformation. For the molecular confirmation, DNA extracts from tissue suspension were used.

The PCR mixture was prepared in total volume of $20 \mu \mathrm{l}$ containing $1 \mu \mathrm{l}$ DNA template, $1 \mu$ l forward primer, $1 \mu$ reverse primer, $7 \mu \mathrm{l}$ nuclease free water and $10 \mu \mathrm{l}$ amplicon master mix.

The B2L gene approximately 592bpwas amplified according to the methods of Inoshima et al., (2001) using partial B2L gene specific primers:

Forward: 5'-GTCGTCCACGATGAGCAGCT3'

Reverse: 5'- TACGTGGGAAGCGCCTCGCT3'

The cycling conditions for the partial B2L gene were: initial denaturation at $95^{\circ} \mathrm{C}$ for 5 minutes, followed by 35 cycles at $95^{\circ} \mathrm{C}$ for 50 seconds, $56^{\circ} \mathrm{C}$ for 60 seconds and $72^{\circ} \mathrm{C}$ for 90seconds, and final extension at $72^{\circ} \mathrm{C}$ for 7 minutes.

The extracted DNA was also screened for PPR to rule out mixed infections and to differentiate the vesicular diseases. N-gene of PPR virus was targeted to amplify 351 bpfragment from the genome using the following primers (Jhala et al., 2009; Couacy Hymann et al., 2002).
Forward primer: 5'TCTCGGAAATCGCCTCACAGACTG -3'

Reverse primer: 5'

CCTCCTCCTGGTCCTCCAGAATCT- 3'.

The thermal cycling conditions were initial denaturation at $94^{\circ} \mathrm{C}$ for 4 minutes followed by denaturation at $94^{\circ} \mathrm{C}$ for 30 seconds, annealing at $55^{\circ} \mathrm{C}$ for 30 seconds and extension at $72^{\circ} \mathrm{C}$ for 30 seconds. The 35 cycles were followed by a final extension at $72^{\circ} \mathrm{C}$ for $10 \mathrm{~min}$.

The amplified products were electrophoresed on 1.5 per centagarose (HiMedia) gel in Tris acetate EDTA (TAE) buffer and visualized in the UV transilluminator.

\section{Results and Discussion}

In the present study, the clinical signs in all the cases reported in different herds from Dharmapuri district of Tamil Nadu were typically descriptive of Contagious ecthyma viz., lesions ranged from nodular lesions onthe muzzle to diffuse proliferative scabs, dry crusts with heavy vascularization leading to inanition (Fig. 1).

They were reported to be anorexic, hyperthermic, dull and depressed. The scabs were often friable and bled easily. The lesions around the mouth were severe in lactating kids feeding on the infected dam. Moreover, the dams had proliferative lesions on their teat and udder due to the infection contracted while feeding by the ailing kids. The occurrence of the disease was reported to be high immediately after the onset of monsoon in the region. The morbidity rate of the disease in the infected herds was 80 per cent and there were no mortality reported in that area.

DNA could be positively extracted from all the clinical samples. 
Fig.1 Affected goat showing typical proliferative scabs and crusts around the mouth and nostrils

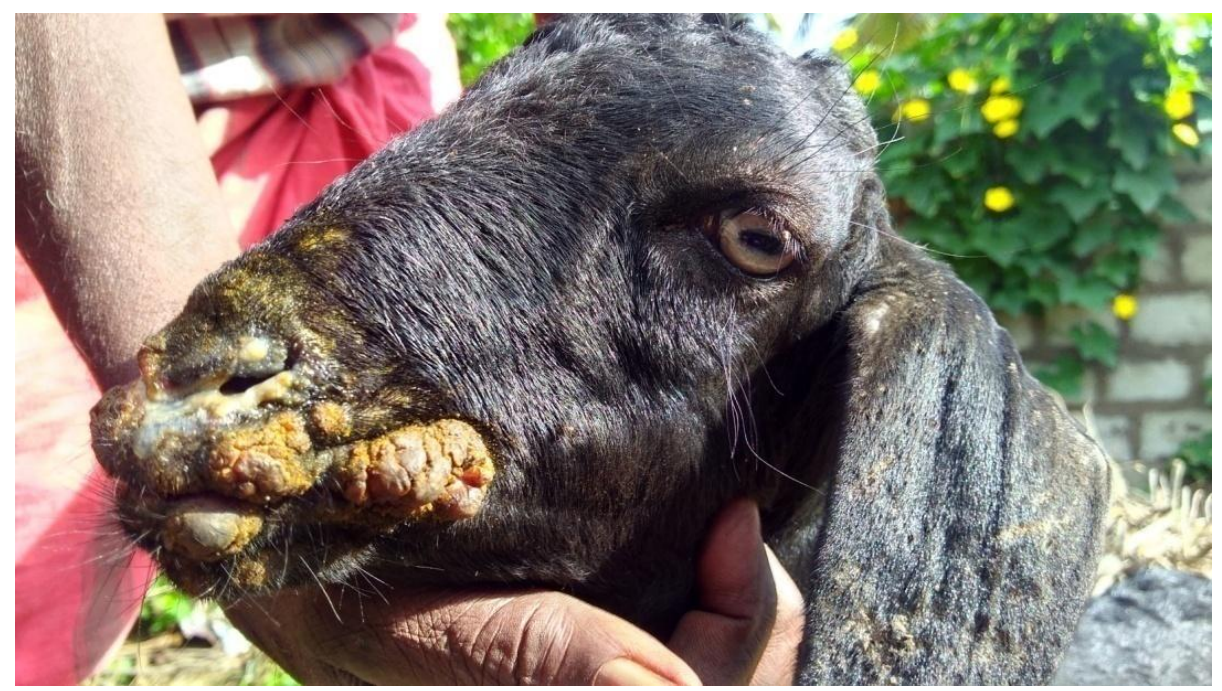

Fig.2 PCR amplification of B2L gene (592 bp) of ORF virus using specific primers. Lane-1: 100 bp DNA ladder; Lane-2: Non template control; Lane- 3-5 positive samples from Dharmapuri district of Tamil Nadu

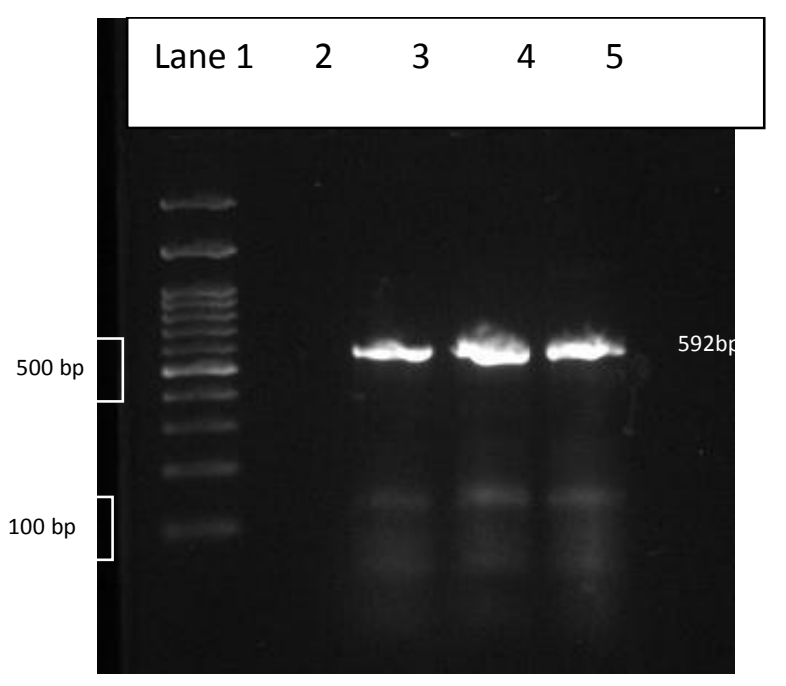

All the ten scab samples collected during the outbreak were subjected to PCR for B2L gene specific for Contagious ecthyma virus.

The likely product of $592 \mathrm{bp}$ fragment of B2L gene of Contagious ecthyma virus could be successfully amplified by PCR from all the samples collected in Dharmapuri district. (Fig. 2). The PCR targeting $\mathrm{N}$ gene of PPR virus confirmed that all the samples were negative for PPR from the affected flocks.
The affected animals recovered after ten days of continuous treatment with antibiotics to prevent secondary bacterial infection and palliative care with boroglycerine paste (Ali et al., 2013).

Orf infection is one among the vesicular diseases universally encountered in sheep and goats. The impact of the disease is considered less significant, since it is a self-limiting disease, though it causes high mortality in 
young lambs and adult animals due to secondary bacterial infection. In the present study, the disease was reported in more number of goats and less in sheep. Goats are generally more susceptible and develop more severe cases of Contagious ecthyma than sheep (Nandi et al., 2011).

The conventional method for diagnosis of Contagious ecthyma by clinical signs and pathological lesions are always confounded by other diseases with similar clinical signs like, pox, PPR, Foot and Mouth Disease (FMD) and vesicular stomatitis etc., Virus isolation from the infected animals is regarded as the confirmatory test for the diagnosis of Contagious ecthyma which is laborious and time consuming (Chan et al., 2007). With advent of molecular biology, PCR technique is being widely used to amplify the desired genomic fragments from tissue specimens of affected animals and it has become a powerful tool in molecular diagnosis (Inoshima et al., 2000). Recently, PCR targeting B2L gene has been developed for confirmatory diagnosis in sheep. In the present study, the PCR technique could amplify the desired gene product as low as $16 \mathrm{ng} / \mu \mathrm{l}$. The efficacy of PCR was comparable to the cell culture/neutralization assays (Zheng et al., 2007).

The analytical specificity of the PCR reaction was checked to rule out the presence of closely related disease like PPR in all the ten clinical samples. The samples were negative for PPR in PCR techniques. The clinical picture together with the molecular confirmation by PCR assured that the outbreak was due to Contagious ecthyma virus infection. Hence, the PCR assay is proved to be very rapid, accurate and cost effective for the diagnosis of Contagious ecthyma without using the cell culture system or electron microscopy during field outbreak.

\section{Acknowledgement}

The authors are thankful to the Dean, Veterinary College and Research Institute, Namakkal for facilities provided for this study.

\section{References}

Abu, E.E., and Housawi, F.M. 1997. Severe long-lasting Contagious ecthyma infection in a goat's kid. Zentralbl. Veterinarmed. Reihe, B 44: 561-564.

Ali, M.H., Ahmed, M.H., Tamam, S.M., Arafa, A., Saad, A.A., Ali, W.F., and Madbouly, H.M.2013. Molecular Characterization of Orf Virus Isolated from Sheep and Goats in Egypt. Global Veterinaria, 11: 98-106.

Apatow, S.M. 2010. One medicine: One Health (Zoonotic Disease) Online Course, Biodefense Reference Library Foreign Animal and Zoonotic Disease Center., 51:771-782.

Bassioukas, K., Orfanidou, A., Stergiopoulou, C.H. and Hatzis, J., 1993. Orf. Clinical and epidemiological study Australas. J. Dermatol., 34(3): 119-123.

Boughton, I.B., and Hardy, W.T. 1935. Immunization of sheep and goats against sore mouth (Contagious ecthyma). Bullet. Texas Agric. Exp. Station., 504:16.

Chan, K.W., Lin, J.W., Lee, S.H., Liao, C.J., Tsai, M.C., Hsu, W.L., Wong, M.L., and Shih H.C. 2007. Identification and phylogenetic analysis of orf virus from goats in Taiwan. Virus Genes, 35: 705712.

Couacy-Hymann, E., Roger, F., Hurard, C., Guillou, J.P., Libeau, G., and Diallo, A. 2002. Rapid and sensitive detection of peste des petits ruminants virus by a polymerase chain reaction assay. $J$ Virol Methods., 100: 17-25. 
De la Concha-Bermejillo, A., Ermel, R.W., Zhang, Z., and Guo, J. 1999. Contagious ecthyma (Orf) virulence factors and vaccine failure. Proceedings of the Annual Meeting on USAHA, 513524.

De Wet, C., and Murie, J. 2011. Lamb pays lip service: two cases of ecthyma contagiosum (orf). Scott. Med. J., 56:59.

Greig, A., Linklater, K.A., and Clark, W.A. 1984. Persistent orf in a ram. Vet. Rec., 115: 149.

Gumbrell, R.C., and McGregor, D.A. 1997. Outbreak of severe fatal orf in lambs. Vet. Rec., 141: 150-151.

Haig, D.M., and Mercer, A.A. 1998. Ovine diseases. Orf. Vet. Res., 29:311-326.

ICTV 2014.

Inoshima, Y., Morooka, A., and Sentsui, H. 2000. Detection and diagnosis of parapoxvirus by the polymerase chain reaction. J Virol Methods., 84: 201-208.

Inoshima, Y., Murakami, K., Yokoyama, T., and Sentsui, H. 2001. Genetic heterogeneity among parapoxviruses isolated from sheep, cattle and Japanese serows (Capricornis crispus). J Gen Virol., 82: 1215-1220.

Ishii, S., Kawakami, Y., and Fukuhara, S. 1953. Pustular dermatitis of sheep and goats. 1. The property of the comparative agent. Exptl. Report. Govt. Exp. Station Anim. Hyg., 27:141-150.
Jhala, M.K., Pooja, C., and Joshi, C.G. 2009. Molecular detection of Peste des petits ruminant virus by using $\mathrm{F}, \mathrm{N}$ and $\mathrm{H}$ genes based RT-PCR. Indian JVirol., 20: $16-18$

Klein, J. 2004. Parapox virus infections in Norwegian Semidomesticated Reinder: Characterization of the causative virus. A Ph.D thesis submitted to the University of Tromso, Norway.

Manley, F.H. 1934. Observations on the virus of contagious pustular dermatitis. Vet J., 90: 80-91.

Nandi, S., De UK., and Choudhary, S. 2011. Current status of Contagious ecthyma or orf disease in goat and sheep- A global perspective. Small Rum. Res., 96: 7382.

Newsom, I.E., and Cross, F. 1934. Sore mouth in feeder lambs due to a filterable virus. J. Am. Vet. Med. Assoc., 84: 231-247.

Zamri-Saad, M., Roshidah, I., al-Ajeeli, K.S., Ismail, M.S., and Kamarzaman, A. 1993. Severe complications induced by experimental bacterial super infection of orf lesions. Trop. Anim. Health. Prod., 25: 85-/88.

Zheng, M., Liu, Q., Jin, N., Guo, J., Huang, X., Li, H., Zhu, W., and Xiong, Y. 2007. A duplex PCR assay for simultaneous detection and differentiation of Capripoxvirus and Orf virus. Mol Cell Probes., 21: 276-281.

\section{How to cite this article:}

Sowmiya, P.V., K. Ramya, K. Sukmar and Madheswaran, R. 2018. Molecular Confirmation of Contagious Ecthyma Among Goats in Dharmapuri District of Tamil Nadu, India. Int.J.Curr.Microbiol.App.Sci. 7(06): 60-65. doi: https://doi.org/10.20546/ijcmas.2018.706.009 